\title{
ICT as a Determinant for Human Progress: Cross- Country Time Series Analyses
}

\author{
Sang-Oun LEE*, Ahreum HONG*, Changjun LEE*, Junseok HWANG* \\ *Technology Management, Economics, and Policy Program, College of Engineering, Seoul National University, Seoul, Korea \\ sangounlee@snu.ac.kr, army78@snu.ac.kr, willbfree@snu.ac.kr, junhwang@snu.ac.kr
}

\begin{abstract}
Hitherto studies regarding ICT diffusion at national/local level mainly focuses on economic growth only by enhanced productivity in domestic industries. As ICT plays a role of General Purpose Technology with its variability and adaptability, this research raise the issue about the relationship between human progress and information and communication technology (ICT) at the national level. Author conducts empirical studies with broader and qualitative factor with ICT diffusion through cross-country panel analysis method to test the hypotheses. The results confirm that ICT can drive human progress at the national level, and also contributes to academia for inspecting future changes with human progress with similar studies.
\end{abstract}

Keywords - ICT, Human Progress, Technology Diffusion, Cross-Country Analysis, Panel Analysis

\section{INTRODUCTION}

Information about final paper submission is available from the conference website. Nowadays, Information and Communication Technology (henceforth ICT) is everywhere with varied forms. The diffusion of ICT seems to be a global phenomenon, rather than privilege of a few developed and developing nations. We see more and more people being connected by technologies, not in local level, but in global level. According to the International Telecommunications Union (henceforth ITU), now the world has 6.8 billion mobile-cellular subscription, in other words, the measure almost have reached to $100 \%$ of the whole global population. In addition, over 2.7 billion people are using the internet, which also corresponds $39 \%$ of the world population. Furthermore, the prices for fixed broadband had dropped by $82 \%$ between 2008 and 2012, which made it more accessible to those who have less [1]. As given data above supports, this global phenomenon is striking in numbers, and naturally ignites number of researches with the impact of diffusion. Not only by given data, but also the sample of this research shows exact trend published by the ITU. The Figure 1 shows the mobile cellular phone subscription per 100 inhabitants of 102 countries from 2000 to 2010 . It is clearly depicted that it is a global trend of one-cell phone-for-everyone still prevails in the sample.

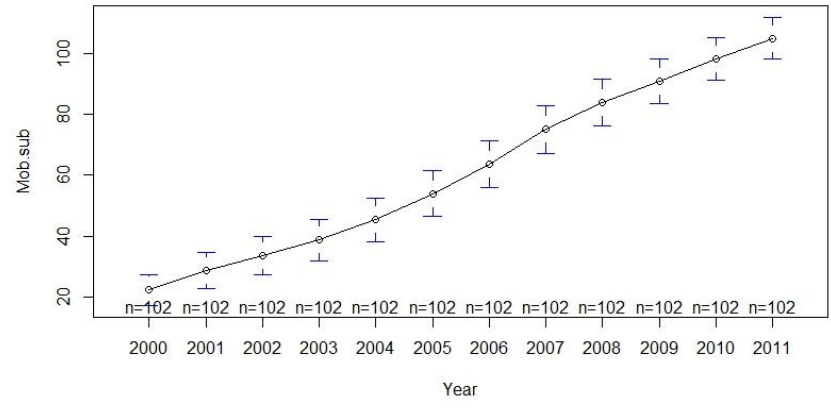

Figure 1 Mobile Cellular Subscription per 100 Inhabitants

As the ICT is developed and diffused, however, the worries about 'digital divide' arises between the wealthy and the poor, not only in individual level, but also in national level as well. Depending on the wealth of nations, diffusion rate of ICT is highly differed because of the cost of infrastructure and national commitments [2]. At the same time, key international development organizations such as United Nations Development Programme [3], and the World Bank, and also Multi-National Corporations [4], are recognizing the facilitation of ICT in the developing world as a key method for bridging the digital divide [5]. Naturally, by the digital divide being a key topic for discourse on development, professionals and academics have started to ask what the role of ICT can play for the further growth.

At the same time, based on the peculiarities, ICT itself is considered as General Purpose Technology (GPT), which notion proposed by Helpman [6], with its variability and adaptability to other technologies or industries [7]. Therefore, the potency of ICT is recognized from various sectors. At the G8 Summit at Okinawa in 2000, leaders had agreed on the power of ICT at the Okinawa Charter on Global Information Society, which expresses ICT as "one of the most potent forces in shaping 21 st century" [8].

Following section contains the literature review which had focused on the potency of ICT in socio-economic changes, and adopted human progress indicators.

\section{LITERATURE REVIEW}

\section{A. Problem Statement}


Even though the diffusion of ICT has omnidirectional impacts over the country, hitherto researches mainly have focused on the relationship between ICT and economic development, or to elaborate, ICT and productivity enhancement. By being the vehicle of transformation ICT is viewed as a catalyst for national development [9]. Research regarding this issue starts with the ground that the ICT as an input will affect the output, which in other words, can expect the enhancement of productivity. However, except for few, the relationship between ICT diffusion and human progress is rarely dealt. At this section, author delivers problem statement divided into two issues, which are firstly, the research trend centered mainly in verifying ICT diffusion and economic development, and secondly, the limitations prevails in measuring human progress by technical changes with prevailing indicators, and lastly, the limitations on prevailing similar studies.

\section{1) ICT and Economic Growth}

In defining the New Economy by Quah [10], which he himself coined 'weightless economy', the term includes ICT and internet; intellectual properties including broader sense such as namebrands and trademarks, advertising, consulting and financial services; electronic databases, and biotechnology. Among them, in emphasizing the IT aspect, Quah [11] argues that since the ICT output has typically little physical manifestation and non-rival or infinitely expansible, ICT differs from other high tech industries displaying increasing returns, in the ground of technological innovation driving the economic growth [12]. Therefore, with its exceptional peculiarities, many studies were done in order to verify the relationship between the ICT and economic development.

In fact, this topic was not brand new from emergence of the Internet, however, it was discussed from the supply of fixed-line telephony. It may be considered as recent phenomena to focus on ICT in economic growth, however the relationship between ICT and economic growth have been examined for a long time since its emergence of fixed-line telephony, a classic technology compared to those of nowadays. For example, telephony, by its features that allowing organizations or society (i) to remove physical constraints between organizational communications, (ii) to achieve higher effectiveness from telecommunications and (iii) to enhance the efficiency of household operations [13]. Grounded with this philosophy, based on United States data, Hardy [14] have argued that the telephone does contribute to economic growth as it being the communicational medium that leads to better allocation of resources, achievement of economies of scale, and advancement in productive knowledge. Around decade after, with the infrastructural level of ICT, Cronin, et al. [15] had conducted time-series analysis of 31 years based on US data, which results have indicated that telecommunications investment affects positively in economic growth, and also stimulates demands in further investment in telecommunications infrastructure. Not only the US, but also a study published by OECD have shown that, over the past two decades, ICT contributed between 0.2 to 0.5 percentage points per year to economic growth, depending on the countries which sample containing Australia, Canada, Finland, France, Germany, Italy, Japan, United Kingdom and the United States [16]. Similar study in Taiwan by Wang [17] also shows evidence in relation between ICT infrastructure and national competitiveness are positively related.

As the diffusion and development of ICT had made its progress, the technological frontier of ICT have been shifted towards. The emergence of the Internet had sparked a general interest in ICTs, including how ICT can help developing world to achieve further growth [18]. Not only with the classic literatures, but also the very recent study in Korea have proven that the ICT convergence enhances the productivity of industries by input-output analysis [19]. In alignment, numerous studies have discussed about the impact of ICT to economy. Cette, et al. [20] have shown the ICT diffusion contributing to potential output growth in the long term, and productivity enhancement in the short term.

However, not every literatures are fully supporting the role of ICT in economic growth in every cases. Lee, et al. [21], conducted cross-country time series analyses and made conclusion that ICT investments have been contributing to improvement in national productivities within developed and newly industrialized economies, but not in developing countries. Also, there also some skepticism on direct impact of ICT to economy. Avgerou [22] was not certain about the direct impact of ICT to the economy, but she discussed about the productivity paradox that ICT diffusion at organizational level is likely to bring redesign of business process and reorganization of work procedure, restructuring of management, or changing the range of products and services which can lead to potential enhancement in productivity.

Therefore, to see the hitherto trends in research regarding ICT and economic development, firstly, it is clearly understandable that there have been many efforts to verify the relationship between two major variables, ICT and economy. Secondly, even if the debate of interrelation is still ongoing, general agreement on ICT affecting the economic development still prevails with evidences.

\section{2) Human Development Index}

Second source for this problem statement is about Human Development Index published annually by the UNDP. Human Development Index (henceforth, HDI) is known as one of the key indicators that can measure human progress. HDI basically started with measuring three pillars of human progress, which are life expectancy, adult literacy, and purchasing power adjusted GDP per capita. The philosophy of this measure starts with the capability approach. Capability approach focuses on distinct capability entails pluralist approach. It sees development a combination of distinct capability development that which things the human value [23]. 
However, even though it is one of key complementary index to measure human factor, criticisms towards HDI are actively discussed. Firstly, Hopkins [24] have expressed his criticisms on putting same weight to literacy, because based on his argument, literacy should be the weakest indicator for it having limits on applying identical standards to different language groups. At methodological level, Sagar and Najam [25] argued about treatment method of the components which could lead to misinterpretation. In addition, McGillivray [26] criticizes that HDI is redundant because of high correlation with per-capital income, and the index largely provides little more information regarding intercountry development levels than GNP per capita. Furthermore, in fundamental level, Baliamoune [27] asks more fundamental question of human well-being, which is when a person living longer than others, does it means he/she is living well than others? Answering such question is still remaining as hurtle for the HDI with its modifications, and also hard to determine the changes from technological diffusion as well.

By HDI having its limitations and criticisms, author intends to explore further human progress by adopting humanbased indicators which could deliver not the capability approach in development, but fundamental level of human being's better-off.

\section{3) Limitations on Measuring ICT diffusion and its Im pact}

Studies regarding the ICT diffusion had started from a single technology level with single country. Again, starting from telephone [14], the diffusion of computers have shown what are the determinants and changes from the adoption of the computers at macro level [28]. In addition, not only single technology, but attempts to measure the development of telecommunication and broadcasting infrastructure was done at the global level, which has wider sample included [29].

Along with the global trend, cross-country analyses of ICT diffusion with larger sample is quite natural. However, studies so far had following limitations in dealing with the ICT diffusion and its impact. Firstly, since the ICT was cutting-edge technology that only the wealthy can own in the past, which became much more affordable nowadays, it delivers limited implications and explanations regarding the impact of ICT diffusion by limited sample. However, as it is acknowledgeable from the data (especially the diffusion of mobile cellular phones reaching $100 \%$ of human population), ICT is no longer a luxury to have limited access, but a door that opened to give broader access to the world. Therefore, to deliver better explanations the impact, cross-country analysis with larger sample should be conducted.

Secondly, former studies are mainly conducted not in lengthy method, but in a momentary method. Therefore, because the analyses were conducted in short time period nearly below 5 years, explanatory power of determinants are also being limited. This is mainly due to the lack of data source that fully reports the data of the globe. For instance, Baliamoune-Lutz [30] have conducted an analysis of the determinants and effects of ICT diffusion in developing countries for 3 years, from 1998 to 2000. Even though she had six important findings about the determinants in ICT diffusion, the result may change by considering the speed of diffusion in last decade. Therefore, for current and future implications of ICT diffusion, the analyses should be conducted with longer period which shows dynamic increase, and even mature level of ICT diffusion.

\section{4) Research Questions and Definitions for the study}

Based on the limitations listed above, author summarizes the problems in the status quo as following. Firstly, hitherto studies related with the impact of ICT diffusion is mainly concentrated with economic development only. Secondly, former related studies had limitations on sample size in crosscountry analysis because of limited data and low rates of diffusion at the global level. Third, the length of empirical analyses to fully explain the implications from the ICT Diffusion. Since 2000, the world have experienced dynamic diffusion of ICT that can differ the past results.

With the problems underlying in the status quo, author raises following research questions. First of all, if economic growth is driven by the ICT, then how about the human progress? Can ICT diffusion make human being better-off? Secondly, by considering that the ICT diffusion have reached mature level globally, what kind of technology among ICT was the key determinant for human progress? Furthermore, when conducting macro-level studies, the effect of ICT diffusion may differ. According to Porter, et al. [31], mentioned that in low income countries, technological innovation may have little significance because the biggest challenge is not new technology but basic market factors. In addition, even though Flor [32] had emphasized the importance of capability for information to lead to opportunities, Howard and Mazaheri [33] discusses about the varied level of technological access links different policies in decreasing the digital divide. Therefore, this research form groups of countries in advanced, intermediate, and low ICT capabilities before the analyses. In this regard, third question to be raised is: How the different income level has effect on the ICT diffusion and the human progress?

In this study author defines the number of notions for accuracy of the research. First of all, human progress is defined as: the comprehensive progress which is made for human being's better off, such as improvement in educational environment, economic activities, healthcare infrastructure, public service, and so on. In addition, the ICT is defined as: technology of communicational medium that can be facilitated by the users. In this research, ICT will cover the technologies of internet, telephone, mobile telephone with including the infrastructural level. 
So far, at the author's best knowledge, the relationship between human progress and ICT diffusion is measured under certain limits. Therefore, to describe the relationship with better explanatory power than the previous studies, author conducts cross-country time series analyses with 102 countries from 2000 to 2011.

\section{B. Human Factors}

\section{1) Freedom}

According to the Universal Declaration of Human Rights (UDHR) by United Nations, human rights is defined as "the right to free communication, religious and political participation, and the right to engage in economic activity" [34]. Freedom is one of the key issue that a human being can be affected by the expansion of ICT. More access to information leads one to resources and opportunities [32], and freedom of access to information should be the common ground for the ICT diffusion. This study divides freedom into three parts in line with UDHR, economic freedom, political freedom, and civil liberty.

So far, some studies had undergone analyses of relationship between the freedom indicators and ICT diffusion. Baliamoune-Lutz [30] inspired the author to adopt three categories of freedom indicators. She conducted empirical study of 47 developing countries with three freedom indicators, index of economic freedom, civil and political freedom index with 4 ICT indicators to find out the key determinant for ICT diffusion, which was income. In addition, Shirazi, et al. [35] have conducted empirical analysis of Islamic Middle Eastern countries' economic freedom and the role of ICT, and later year, Shirazi, et al. [36] have verified the relationship between political freedom. Both studies by Shirazi et al. have shown that the ICT and freedom indicators had positive correlation.

Likewise, studies with ICT diffusion and economic, political, and civil freedom separately, with limited sample. Therefore, in this study, author conducts comprehensive analyses with larger sample, not limited to the geographical boundaries, with longer time series. The explanation of data and analyses method will be introduced in the later section of this paper.

\section{2) Urbanization}

Cities are likely to have better industrial infrastructure, better educational environment, better services, more jobs, and better quality of life due to concentration of resources from nationwide. Author have included urbanization into human progress because the urbanization complementarily affects human lives. Bertinelli and Black [37] had argued that the urbanization has played a key role in the process of development. According to Harter, et al. [38], urbanization is described as "inevitable progression." They have shown the cases that in the long term of urbanization which is inevitable,
ICT can make changes bringing social equitability, economic viability, and also environmental sustainability in the cities. Also, Njoh [39] have conducted empirical study of correlation analysis between the Human Development Index and urbanization process in sub-Saharan region, which turned out to have positive association between the two variables. To sum up, the above literatures about urbanization emphasizes that the term itself is important factor in measuring development.

Even though prior study have verified positive correlation between the human development index and urbanization in sub-Saharan area, the reasons for this study being pursued follow. Firstly, because the sample is limited, it is available to make more contribution by expanding the sample. Secondly, because human development index is inappropriate for measuring impact of technological diffusion and human progress by including the ICT indicators itself inside the composite index. Therefore, this study includes urbanization into human progress indicator to analyze the relationship with ICT diffusion variables.

\section{3) Education}

Education have long been a key measure, or key driver for human progress. With education, even though we are aware that it is unavailable to see direct impact by input because it's a timely process, human potential finds higher possibility to be maximized properly wide widened opportunities. Philosophically, primary education leads human being to be a member of a society with basic knowledge by language, math, basic science, and so on. Secondary education leads human being to search for their interests and talents. Tertiary education, which also includes higher or further education, drives human potential to be extracted into actual form of knowledge.

Likewise, ICT also shares similar role with education in driving human progress. For ICT being the enabling technology, education plays a role of enabling instrument to human being. Scholars who touched this issue have proven that the highly interrelated features between the education and ICT. Before getting into the ICT, through regressions between diffusion of technology and human capital, Lee [40] argued that education plays a key role in technological capabilities in aspect of human capital. In addition, because of shared virtues, hitherto studies have tried to specify the relationship between education and ICT. Starting from the One-Laptop-Per-Child project by MIT designed to allow computing experiences to schooling children [41], number of efforts are currently undergone in order to assist for the poor to have computing device that is affordable and usable for educational purpose [42]. Not only technological level, but also scholars have emphasized the role of ICT in education. Downing [43], by analyzing the healthcare education system and ICT, have argued that sufficient motivation and policy integration leads ICT diffusion to affect positively with education. [Green and 
Gilbert [44]] suggest information technology investment portfolio in educational sector that can enhance the overall quality of education, and especially in higher education.

Therefore, the third component for human progress indicator will be adopting education variable. This education will especially adopt the tertiary education data, because the ICT can play the most potent part in learning experience rather than primary or secondary education. Further descriptions regarding data and variables will be provided in the later section of the paper.

\section{Hypotheses}

Based on given research questions and literature review, author aims to test the following hypotheses and subhypotheses:

H1. National level ICT diffusion can take the role as a determinant for human progress.

H2. By different technological category inside the ICT, the potency of impact will be differed.

H2.1. Internet is the strongest determinant for driving human progress in measuring impact of human progress by ICT diffusion

H2.2. Fixed line telephone is the weakest determinant in measuring impact of human progress by ICT diffusion

The Internet as the strongest determinant is based on the following reasons. Firstly, the Internet is available to communicate in two ways with varied form of information transmission. Not only the text form, but also the form in image, voice, video in real time is possible through the Internet. Even though the mobile phone of nowadays allowed this peculiarities in mobile, but still there is variations between samples whether the population is adopted with the $3 \mathrm{G}$ or higher (in other words, smart phones with internet access) or only classic form of mobile cellular phone. Therefore, the Internet was expected to have the strongest determinant. Fixed line telephone was also selected as the weakest, because of its decreasing in trends worldwide.

H3. The impacts on human progress by national level ICT diffusion are differed by the income level of that country.

H3.1. Middle level income group will have the strongest impact in measuring impact of human progress by ICT diffusion

H3.2. Low income group will have the weakest impact in measuring impact of human progress by ICT diffusion

Logical basis of sub-hypotheses of $\mathrm{H} 3$ is based on the following reasons. Firstly, H3.1. is started from the intuition that the middle level income group, which is in other words, developing countries, would be having the most dynamic changes for human progress. Rapid socio-economic changes can allow us to expect that it will have the most explanatory power from the technical diffusion, which is ICT diffusion for this study. In addition, the low income group is expected to have the weakest impact because of lacking infrastructure and educational level to accept the diffused ICT.

Following section of this paper includes the introduction of research model and methodologies, result, and conclusion for this research.

\section{Methodology}

\section{A. Data}

This study mainly divides the dataset into two groups, which are ICT data and human progress data. As mentioned above on the definition of this study, the scope of ICT limits to the Internet, fixed-line telephone, and mobile telephone. Additionally, the study also imports ICT infrastructure data. Data source is mainly from World Telecommunication ICT Indicators by ITU with some omitted variables supplemented from the World Development Indicators by World Bank. The list of variables and correlations are described in the following table.

TABle 1 ICT INDICATORS DESCRIPTIONS

\begin{tabular}{|l|l|}
\hline \multicolumn{2}{|c|}{ ICT Variables Descriptions } \\
\hline fis100 & Fixed Line Internet Subscription per 100 Inhabitants \\
\hline fts100 & $\begin{array}{l}\text { Fixed Line Telephone Subscription per 100 } \\
\text { Inhabitants }\end{array}$ \\
\hline mcs100 & $\begin{array}{l}\text { Mobile Cellular Phone Subsctiption per 100 } \\
\text { Inhabitants }\end{array}$ \\
\hline pmcn & $\begin{array}{l}\text { Percentage of the population covered by a mobile- } \\
\text { cellular network }\end{array}$ \\
\hline
\end{tabular}

TABLE 2 CORRELATION AMONG ICT INDICATORS

\begin{tabular}{|lcccc|}
\hline & fis100 & fts100 & pcmn & mes100 \\
\hline fis100 & 1.0000 & & & \\
fts100 & 0.8306 & 1.0000 & & \\
pcmn & 0.4516 & 0.5477 & 1.0000 & \\
mcs100 & 0.6577 & 0.5651 & 0.6052 & 1.0000 \\
\hline
\end{tabular}

Even though the correlation between fis100 and fts100 is 0.83 , which usually cannot be analyzed, in this research, author adopted to use both variable because by grouping, it will show different results, and also the trend of fts 100 is decreasing, which is contrasted to the trend of fis 100.

Human progress data is not from the single source, but multiple sources in order to cover the key disciplines in human progress. Introduced in the literature review above, human progress data are composed with three big categories of (i) freedom, (ii) urbanization, and (iii) education. Freedom 
indicators are collected from two different sources, which are the Freedom House and the Heritage Foundation. From Freedom House, the study imports Political Rights and Civil Liberty data. Since 1973, Freedom house had published an annual report called "Freedom in the World" containing the imported data. Based on independent investigation, the Freedom House reports the ranking of human rights of the world. In addition, the Heritage Foundation, a globally recognized think tank based on the United States, reports the Economic Freedom Index which measures the freedom of economy at national level. Adopting economic freedom index to human progress indicator gives background for excluding income as independent variable, and similar approach is already used by Baliamoune-Lutz [30] with shorter period compared to this study.

Secondly, the urbanization data is imported from the World Development Indicator by the World Bank. Based on number of studies above, the urbanization is commonly measured by the ratio of urban population and the whole population. Lastly, education data is the enrolment of tertiary education from UNESCO statistics. All the selection of variables are based on the literature review from the previous section. Following tables are summary of description for the human progress variables, and correlations.

TABle 3 Human Progress IndicAtors

\begin{tabular}{|c|c|c|c|}
\hline \multicolumn{4}{|c|}{ Human Progress Indicators } \\
\hline Var. & Description & Data Source & Period \\
\hline ef & Economic Freedom & $\begin{array}{c}\text { Heritage } \\
\text { Foundation }\end{array}$ & $2000 \sim 2011$ \\
\hline $\mathrm{pr}$ & Political Rights & $\begin{array}{c}\text { Freedom } \\
\text { House }\end{array}$ & $2003 \sim 2011$ \\
\hline cl & Civil Liberty & $\begin{array}{c}\text { Freedom } \\
\text { House }\end{array}$ & $2003 \sim 2011$ \\
\hline urb & Urbanization Ratio & World Bank & $2000 \sim 2011$ \\
\hline tedu & $\begin{array}{c}\text { Tertiary Education } \\
\text { Enrollment }\end{array}$ & UNESCO & $2000 \sim 2011$ \\
\hline
\end{tabular}

Furthermore, the following table 5 indicates the descriptive statistics of each selected variables.

TABLE 4 DESCRIPTIVE STATISTICS FOR VARIABLES

\begin{tabular}{|l|l|l|l|l|l|}
\hline Var. & Obs. & Mean & $\begin{array}{l}\text { Standard } \\
\text { Deviation }\end{array}$ & Min & Max \\
\hline fis100 & 1099 & 9.856684 & 11.71756 & .0125952 & 53.86814 \\
\hline fts100 & 1223 & 23.80123 & 19.84626 & .1676314 & 74.68774 \\
\hline pcmn & 958 & 89.37589 & 18.27433 & 5.2 & 100 \\
\hline
\end{tabular}

\begin{tabular}{|l|l|l|l|l|l|}
\hline mes100 & 1224 & 61.59398 & 44.70097 & .0314238 & 214.7223 \\
\hline pr & 918 & 63.08279 & 32.4911 & 0 & 110 \\
\hline cl & 918 & 64.76943 & 26.36481 & 5 & 100 \\
\hline ef & 1224 & 61.92083 & 10.80672 & 21.4 & 90 \\
\hline urb & 1224 & 61.01043 & 22.47769 & 12.082 & 100 \\
\hline tedu & 891 & 38.66677 & 25.06639 & .28009 & 118.1017 \\
\hline d1 & 1224 & .3921569 & .4884309 & 0 & 1 \\
\hline d2 & 1224 & .5 & .5002044 & 0 & 1 \\
\hline d3 & 924 & .1428571 & .3501166 & 0 & 1 \\
\hline
\end{tabular}

Firstly, by sample dataset being a panel data, which also known as longitudinal or cross-sectional time series data, it is available to observe the behavior of entities over time [45]. For this research, the entity becomes the countries composing the sample. The list of sample countries are depicted on the following table.

TABle 5 List of SAMPle Countries

\begin{tabular}{|l|l|l|}
\hline \multicolumn{3}{|c|}{ Countries (n=102) } \\
\hline \multicolumn{1}{|c|}{ High income } & \multicolumn{1}{|c|}{ Middle income } & \multicolumn{1}{c|}{ Low income } \\
\multicolumn{1}{|c|}{ (n=50) } & \multicolumn{1}{|c|}{ (n=11) } \\
\hline Australia Austria & Albania & \\
Bahrain Belgium & Argentina & Bangladesh \\
Canada Chile & Armenia & Faso Cambodia \\
Croatia Cyprus & Azerbaijan & Kenya \\
Czech Republic & Belarus Bosnia & Kyrgyzstan \\
Estonia France & and Herzegovina & Malawi Rwanda \\
Germany Greece & Brazil Bulgaria & Uganda \\
Hong Kong & Cameroon Cape & Zimbabwe \\
Iceland Ireland & Verde China & \\
Israel Italy Japan & Colombia Cuba & \\
Korea (Rep. of) & Djibouti Ecuador & \\
Lithuania & Egypt El & \\
Luxembourg & Salvador Fiji & \\
Malta & Gabon Georgia & \\
Netherlands New & Ghana Honduras & \\
Zealand Norway & Hungary India & \\
Oman Poland & Jordan Lao & \\
Portugal Qatar & P.D.R. Malaysia & \\
Saudi Arabia & Mauritania & \\
Singapore Slovak & Mauritius Mexico & \\
Republic & Moldova & \\
\hline
\end{tabular}




\begin{tabular}{|l|l|l|}
\hline Slovenia Spain & Mongolia & \\
Sweden & Morocco Pakistan & \\
Switzerland & Panama Peru & \\
United Arab & Philippines & \\
Emirates United & Romania Senegal & \\
Kingdom United & Sri Lanka & \\
States & Swaziland Syria & \\
& Tunisia Turkey & \\
& Ukraine & \\
& Uzbekistan & \\
& Venezuela Viet & \\
& Nam Yemen & \\
& Zambia & \\
\hline
\end{tabular}

The sample selection is based on data availability of under consideration of every variables. Therefore, because it is based on data availability, the balance of each group is violated. Income categories were adopted from the World Bank. The World Bank classifies the income group according to 2012 Gross National Income per capita, calculated using the World Bank Atlas method. The groups are lower income, $\$ 1,035$ or less; lower middle income, $\$ 1,036 \sim \$ 4,085$; upper middle income, $\$ 4,086 \sim \$ 12,615$; and high income, $\$ 12,616$ or more [46]. In this research, middle income countries are both combined and separated by corresponding research methods.

\section{B. Fixed Effects Model}

Research methods of this research starts from panel data analyses, which contains comparison of estimators by fixed effect and random effect. Firstly, fixed effect model explores the relationship between predictor and outcome variables with an entity, which is country in this study. Each country has own individual its own peculiarities that may or may not influence the predictor variables. The use of fixed effect analysis should preconditioned with assumption that within the individual may impact or bias the predictor or outcome variables and the control is needed. In addition, fixed effect model is that those time-invariant characteristics are unique to the individual and should not be correlated with other individual characteristics, which leads to the need of Hausman test [47]. The equation for fixed model follows:

$Y_{i t}=\beta_{1} X_{1 i t}+\beta_{2} X_{2 i t}+\beta_{3} X_{3 i t}+\beta_{4} X_{4 i t}+\beta_{5} X_{5 i t}+\alpha_{i}+u_{i t}$

Where $Y_{i t}$ is the dependent variable where i=country and $\mathrm{t}=$ time, $X_{i t}$ representing one independent variable, $\beta_{1}$ being the coefficient for that independent variable, and $u_{i t}$ for being the error term.

Since fixed effects model controls for all time-invariant differences among individuals, coefficients which estimated through fixed-effects models cannot be biased because of omitted time-invariant characteristics. One side effect of fixed effects model is that they are unavailable to be used for investigation of time-invariant causes of the dependent variables. Fixed effects models are designed to study causes of changes within an entity. Since it is constant for each person, a time-invariant characteristic cannot cause such a change [48].

Title must be in 24 pt Regular font. Author name must be in 11 pt Regular font. Author affiliation must be in 10 pt Italic. Email address must be in 9 pt Courier Regular font.

\section{Random Effects Model}

Unlike the fixed effects model, random effects model innate the rationale of the variation across entities is assumed to be random and uncorrelated with the predictor or independent variables included in the model. Greene [49] argues that between the random and fixed effects, the crucial distinction is whether unobserved individual effect embodies elements that are correlated with the regressors in the model, not whether these effects are stochastic or not. Thus, if there prevails a reason that differences across countries have some influence on dependent variable, random effects should be used.

Random effects model, compared to fixed effects model the time invariant variables being absorbed by the intercept, has an advantage of including time invariant variables. The model of random effects model follows:

$Y_{i t}=\beta_{1} X_{1 i t}+\beta_{2} X_{2 i t}+\beta_{3} X_{3 i t}+\beta_{4} X_{4 i t}+\beta_{5} X_{5 i t}+\alpha+u_{i t}+\varepsilon_{i t}$

Where $u_{i t}$ is between-country error and $\varepsilon_{i t}$ is within-country error. Underlying premise of assumption that the random effects have is for error term of the country (entity) not being correlated with the predictors that allows for time-invariant variables to play a role as explanatory variables [50].

\section{Hausman Test}

In making decision whether to use fixed effects model or random effects model, Hausman test is used which null hypothesis is that the preferred model is random versus fixed effects [51]. If conducted Hausman test has P-value lower than 0.05 , it is significant to use fixed effects, and if higher than the 0.05 , use random effects. The Hausman statistic is:

$$
\mathrm{H}=\left(b_{F E}-b_{R E}^{\prime}\right)\left[\operatorname{Var}\left(b_{F E}\right)-\operatorname{Var}\left(b_{R E}\right)\right]^{-1}\left(b_{F E}-b_{R E}\right)
$$

Where the statistic is asymptotically the chi-squared distribution with the number of degree of freedom equal to the rank of matrix $\operatorname{Var}\left(b_{F E}\right)-\operatorname{Var}\left(b_{R E}\right)$.

\section{E. The Chow Test}

d The Chow test is a econometric testing method of whether the two coefficients in two linear regressions on different data 
sets are equal [52]. It is most commonly tested in time series analysis to test for the presence of a structural break [53]. Also, in policy evaluating methods, chow test is often used to determine whether the independent variables have different impacts on different subgroups of the population.

In this research, Chow test is conducted to poolability. According to Baltagi [45], poolability asks whether slopes are the same across the group over time. The null hypothesis of Chow test is the slope of a regressor is the same regardless of individual for all $\mathrm{k}$ regresors, $H_{0}: \beta_{i k}=\beta_{k}$. The slopes remain constant in fixed and random effect models; only intercepts and error variances matter.

$F\left[(n-1)(k+1), n(T-k-1)=\frac{\left(e^{\prime} e-\sum e_{i}^{\prime} e_{i}\right) /(n-1)(k+1)}{\sum e_{i}^{\prime} e_{i} / n(T-k-1)}\right.$

Where $e^{x} e$ is the SSE of the pooled OLS and $e_{i}^{x} e_{i}$ is the SSE of the pooled OLS for group $i$. When null hypothesis is rejected, the panel data are not poolable [54]. By grouping the sample, validation for this poolability should be tested to compare the income groups.

\section{IV.RESULTS}

\section{A. Testing Hypotheses 1 and 2}

TABle 6 Pooled Result

\begin{tabular}{|c|c|c|c|c|c|}
\hline & ef_fe & pr_fe & cl_fe & urb_fe & tedu_fe \\
\hline $\begin{array}{l}\text { Fis } \\
100\end{array}$ & $\begin{array}{l}0.143 \\
* * * \\
(.025)\end{array}$ & $\begin{array}{l}0.004 \\
(.004)\end{array}$ & $\begin{array}{l}-0.013 \\
(.034)\end{array}$ & $\begin{array}{l}0.043^{* * * *} \\
(.009)\end{array}$ & $\begin{array}{l}0.429 * \\
* * \\
(.062)\end{array}$ \\
\hline $\begin{array}{l}\text { Fts } \\
100\end{array}$ & $\begin{array}{l}0.010 \\
(.033)\end{array}$ & $\begin{array}{l}- \\
0.186 * * \\
* \\
(.066)\end{array}$ & $\begin{array}{l}-0.039 \\
(.046)\end{array}$ & $\begin{array}{l}0.029 * * * \\
(.012)\end{array}$ & $\begin{array}{l}- \\
0.206 * \\
* * \\
(.073)\end{array}$ \\
\hline $\begin{array}{l}\text { pc } \\
\text { mn }\end{array}$ & $\begin{array}{l}-0.005 \\
(.010)\end{array}$ & $\begin{array}{l}0.035 \\
(.022)\end{array}$ & $\begin{array}{l}- \\
0.033 * * \\
* \\
(.015)\end{array}$ & $\begin{array}{l}0.017 * * * \\
(.003)\end{array}$ & $\begin{array}{l}0.015 \\
(.024)\end{array}$ \\
\hline $\begin{array}{l}\text { mes } \\
100\end{array}$ & $\begin{array}{l}0.013 \\
* * * \\
(.004)\end{array}$ & $\begin{array}{l}-0.013 \\
(.008)\end{array}$ & $\begin{array}{l}0.018 * * \\
* \\
(.005)\end{array}$ & $\begin{array}{l}0.020^{* * * *} \\
(.001)\end{array}$ & $\begin{array}{l}0.104 * \\
* * \\
(.010)\end{array}$ \\
\hline
\end{tabular}

Table 9 reports the pooled panel results for comparing fixed effects model and random effects model through the Hausman test. Based on the result, at the global level (pooled), economic freedom can be explained better with fixed effects model. In economic freedom category, fixed internet subscription per 100 inhabitants reported coefficient of 0.1432 at $1 \%$ statistical significance, which is positively correlated. In addition, the mobile subscriptions per 100 inhabitants reported coefficient of 0.012 at $1 \%$ statistical significance, which also is positively correlated with economic freedom.

Political rights had better explanation through fixed effects model. With fixed telephone subscription per 100 inhabitants, political rights reported coefficient of -0.1865 at $1 \%$ statistical significance, which is negatively correlated. This negative relation insists that there are transition of technologies from fixed line telephone to mobile telephone. Following figure gives this insight, which shows decreasing trend of fixed line telephone subscription, and contrasted trend of increase in mobile telephone subscription.

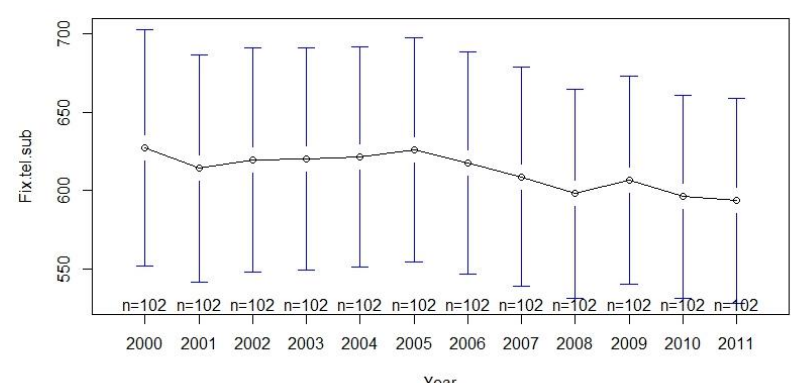

Figure 2 Fixed Line Telephone Subscription per 100 Inhabitants of 102 Sample Countries

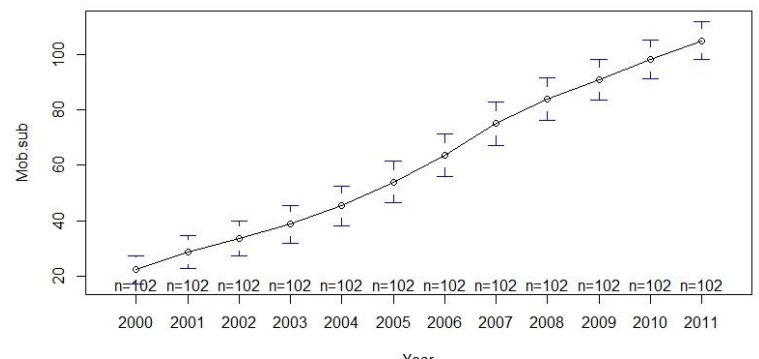

Figure 3 Mobile Cellular Subscriptions per 100 Inhabitants of 102 Sample Countries

Civil liberty, based on the Hausman result, is better explained through fixed effects model as well. Two independent variables, which are percentage of population covered by mobile network and mobile cellular subscriptions per 100 inhabitants reported significant. At $1 \%$ statistical significance, percentage of population covered by mobile network marked coefficient of -0.0332, and mobile subscription per 100 inhabitants marked coefficient of 0.0183 .

Urbanization is also better represented with fixed effects model. Urbanization had shown interesting result that all the ICT diffusion indicators reported 1\% statistical significance with positive correlation. Fixed line Internet subscription per 100 inhabitants marked coefficient of 0.0438 , fixed telephone subscription per 100 inhabitants reported 0.0294 , percentage of population covered by mobile network showed 0.0178 , and mobile cellular subscription per 100 inhabitants marked coefficient of 0.020 . 
Tertiary education had also reported three $1 \%$ statistical significance level except percentage of population covered by mobile network. Fixed Internet subscription per 100 inhabitants reported coefficient of 0.4298 , fixed telephone subscription per 100 inhabitants reported -0.2065 , and mobile subscription per 100 inhabitants marked coefficient of 0.1047 Therefore, at the global level, both hypotheses $H 1$ and $H 2$ are tested to be true.

Since the composition of independent variables are all different measures are from varied sources with different scales, it is difficult to determine whether fixed effect or random effects has higher explanatory power for this panel analysis. Therefore, author conducts series of Hausman tests to find the better determinant coefficient in conveying explanations about relationship between the ICT diffusion and human progress.

Firstly, the sample was divided into 4 groups by income level, which are high income, upper middle income, lower middle income, and low income. Background for grouping the sample into four by income level is to determine the effect of independent variables, which are ICT diffusion indicators, in groups.

After, each divided group had conducted regression with both fixed effect model and random effect model. Then, based on both fixed and random effect regression results stored, the Hausman test is conducted to determine the better determinant between the two. The results for first trial is expressed on the following table.

Table 7 Hausman Test Trial 1

\begin{tabular}{|c|c|c|c|c|c|}
\hline $\begin{array}{c}\text { Trial } \\
1\end{array}$ & $\begin{array}{l}\text { High } \\
\text { Income }\end{array}$ & $\begin{array}{l}\text { Upper } \\
\text { Middle }\end{array}$ & $\begin{array}{l}\text { Lower } \\
\text { Middle }\end{array}$ & $\begin{array}{l}\text { Low } \\
\text { Income }\end{array}$ & $\begin{array}{l}\text { Pooled } \\
\text { Panel }\end{array}$ \\
\hline Ef & $\begin{array}{l}\text { Random } \\
\text { Fis100(+) } \\
\text { Fts100(+) }\end{array}$ & $\begin{array}{l}\text { Fixed } \\
\text { FIS100(+) } \\
\text { PCMN(-) }\end{array}$ & $\begin{array}{l}\text { Fixed } \\
\text { FIS100(+) }\end{array}$ & $\begin{array}{l}\text { Random } \\
\text { PCMN(+) } \\
\operatorname{MCS} 100(-)\end{array}$ & $\begin{array}{l}\text { Fixed } \\
\text { Effect }\end{array}$ \\
\hline Pr & $\begin{array}{l}\text { Fixed } \\
\text { MCS100(+) }\end{array}$ & $\begin{array}{l}\text { Random } \\
\text { MCS100(+) }\end{array}$ & $\begin{array}{l}\text { Random } \\
\text { FIS100(-) } \\
\text { PCMN(+) }\end{array}$ & insignificant & $\begin{array}{l}\text { Fixed } \\
\text { Effect }\end{array}$ \\
\hline Cl & $\begin{array}{l}\text { Failed to } \\
\text { meet } \\
\text { asymptotic } \\
\text { assumptions }\end{array}$ & $\begin{array}{l}\text { Random } \\
\text { MCS100(+) }\end{array}$ & $\begin{array}{l}\text { Failed to } \\
\text { meet } \\
\text { asymptotic } \\
\text { assumptions }\end{array}$ & insignificant & $\begin{array}{l}\text { Fixed } \\
\text { Effect }\end{array}$ \\
\hline urb & $\begin{array}{l}\text { Random } \\
\text { FIS100(+) } \\
\text { FTS100(+) }\end{array}$ & $\begin{array}{l}\text { Random } \\
\operatorname{PCMN}(+) \\
\operatorname{MCS} 100(+)\end{array}$ & $\begin{array}{l}\text { Random } \\
\operatorname{MCS} 100(+)\end{array}$ & $\begin{array}{l}\text { Random } \\
\text { PCMN(+) } \\
\operatorname{MCS} 100(+)\end{array}$ & $\begin{array}{l}\text { Fixed } \\
\text { Effect }\end{array}$ \\
\hline Tedu & $\begin{array}{l}\text { Fixed } \\
\text { MCS100(+) }\end{array}$ & $\begin{array}{l}\text { Failed to } \\
\text { meet } \\
\text { asymptotic } \\
\text { assumptions }\end{array}$ & $\begin{array}{l}\text { Failed to } \\
\text { meet } \\
\text { asymptotic } \\
\text { assumptions }\end{array}$ & $\begin{array}{l}\text { Fixed } \\
\text { FTS100(+) } \\
\text { FIS100(-) } \\
\text { MCS100(+) }\end{array}$ & $\begin{array}{l}\text { Fixed } \\
\text { Effect }\end{array}$ \\
\hline
\end{tabular}

According to the first trial of the Hausman test followed by fixed effect model and random effect model regression, among 20, 16 had identified its outcome for whether random or fixed effect model is appropriate in explaining the relationships, with which independent variable had positive or negative relations. Most of the independent variables, ICT diffusion indicators, had positive impact on economic freedom, political rights, civil liberty, urbanization and tertiary education. The Internet was the most reported determinant to the human progress indicators with random and fixed effects following to the first trial of Hausman test.

Still, in cases of relations between civil liberty and high income group, civil liberty and lower middle income group, tertiary education and upper middle income group, tertiary education and lower middle income group cannot determine the appropriate model and determinant. Thus, to specify the two covariance matrices used in the test to be based on a common estimate of disturbance variance. It provides more efficient estimator and the result whether test of overidentification exists. The Hausman test with sigmamore option conducted second trial for selected four cases and determined between both effects. Based on the second trial, the final results can be made as following table.

Table 8 Hausman Test Trial 2

\begin{tabular}{|c|c|c|c|c|c|}
\hline $\begin{array}{c}\text { Trial } \\
2\end{array}$ & $\begin{array}{l}\text { High } \\
\text { Income }\end{array}$ & $\begin{array}{l}\text { Upper } \\
\text { Middle }\end{array}$ & $\begin{array}{l}\text { Lower } \\
\text { Middle }\end{array}$ & $\begin{array}{l}\text { Low } \\
\text { Income }\end{array}$ & $\begin{array}{l}\text { Pooled } \\
\text { Panel }\end{array}$ \\
\hline Ef & $\begin{array}{l}\text { Random } \\
\text { FIS100(+) } \\
\text { FTS100(+) }\end{array}$ & $\begin{array}{l}\text { Fixed } \\
\text { FIS100(+) } \\
\text { PCMN(-) }\end{array}$ & $\begin{array}{l}\text { Fixed } \\
\text { FIS100(+) }\end{array}$ & $\begin{array}{l}\text { Random } \\
\text { PCMN(+) } \\
\operatorname{MCS} 100(-)\end{array}$ & $\begin{array}{l}\text { Fixed } \\
\text { Effect }\end{array}$ \\
\hline Pr & $\begin{array}{l}\text { Fixed } \\
\text { MCS100(+) }\end{array}$ & $\begin{array}{l}\text { Random } \\
\operatorname{MCS100(+)}\end{array}$ & $\begin{array}{l}\text { Random } \\
\text { FIS100(-) } \\
\text { PCMN(+) }\end{array}$ & insignificant & $\begin{array}{l}\text { Fixed } \\
\text { Effect }\end{array}$ \\
\hline Cl & $\begin{array}{l}\text { Random } \\
\text { MCS100(+) }\end{array}$ & $\begin{array}{l}\text { Random } \\
\text { MCS100(+) }\end{array}$ & $\begin{array}{l}\text { Random } \\
\text { FIS100(-) }\end{array}$ & insignificant & $\begin{array}{l}\text { Fixed } \\
\text { Effect }\end{array}$ \\
\hline Urb & $\begin{array}{l}\text { Random } \\
\text { FIS100(+) } \\
\text { FTS100(+) }\end{array}$ & $\begin{array}{l}\text { Random } \\
\text { PCMN(+) } \\
\operatorname{MCS} 100(+)\end{array}$ & $\begin{array}{l}\text { Random } \\
\text { MCS100(+) }\end{array}$ & $\begin{array}{l}\text { Random } \\
\text { PCMN(+) } \\
\operatorname{MCS} 100(+)\end{array}$ & $\begin{array}{l}\text { Fixed } \\
\text { Effect }\end{array}$ \\
\hline Tedu & $\begin{array}{l}\text { Fixed } \\
\text { MCS100(+) }\end{array}$ & insignificant & $\begin{array}{l}\text { Fixed } \\
\text { FIS100(-) } \\
\text { MCS100(+) }\end{array}$ & $\begin{array}{l}\text { Fixed } \\
\text { FTS100(+) } \\
\text { FIS100(-) } \\
\text { MCS100(+) }\end{array}$ & $\begin{array}{l}\text { Fixed } \\
\text { Effect }\end{array}$ \\
\hline
\end{tabular}

According to panel regression analyses and Hausman tests, following results can be stated. Firstly, by determining the appropriate model of effect whether it should be random or fixed, it is available to derive appropriate determinant for given human progress effects.

Economic freedom have shown general impacts from the diffusion of ICT. Especially, except for the low income country, diffusion of the Internet has positive correlation with improvement in economic freedom. In case of upper middle income level countries, variable PCMN, percentage of mobile network coverage, is negatively affects the economic freedom. For this phenomenon, it must be in relation of saturation level of mobile phone diffusion. More and more investment in mobile infrastructure, for example, diffusion of $4 \mathrm{G}$ networks, might lead to economic inefficiency that disturbs in enhancement of economic freedom. However, in the low income level country group, as mobile network coverage gets wider, based on the results, it is positively correlated with the economic freedom. In contrast, because the mobile cellular subscription per 100 inhabitants showing negative coefficient in relation with economic freedom, which shows contrasts in 
the mobile infrastructure variable, it is difficult for making conclusion for the impact of ICT diffusion to economic freedom in low income countries.

Political rights have shown interesting results. Countries in high and upper middle income groups, both shown having positive relationship between political rights indicator and mobile cellular phone subscription per 100 inhabitants. Again, as the globe is in the age of one-mobile-phone-per-person, it is likely to have more and more communications regardless of geographical distance. Under the very spirit of democracy, more and more discourse and debate leads to active participation in politics. With ICT, representative democracy of modern days is again integrating with grass-roots-direct democracy. Consequently, the result for positive correlation between political rights seems natural. At lower middle income countries, political rights are negatively correlated with fixed internet subscription and positively with mobile infrastructure coverage. This may calls the problems in the cost of fixed line internet is even higher than the mobile network infrastructure. However, still it follows the logic of mobile technology having positive correlation with political rights, in line with high and upper middle income groups. For countries of low income group, have shown insignificant results. This insignificancy will be dealt in the later section.

Civil Liberty, also in line with political rights, shows similar results with related technology indicator, the mobile cellular phone subscription per 100 inhabitants. Both in high and upper middle income group have shown positive relationship between civil rights and diffusion of cellular phone at national level. However, in lower middle income group, it is shown that the fixed line internet subscription per 100 inhabitants has negative relationship with civil liberty. Again, in low income group, every technological indicators were turned out to be insignificant with civil liberty.

Urbanization index is the only index that shows every countries within each group showing positive relationship with ICT diffusion. At the same time, it delivers interesting results because only the high income group is showing positive relationship with fixed line internet subscription per 100 inhabitants, and others are related with mobile technology. In addition, even at the low income group, the diffusion of mobile technology at the product level and infrastructural level, both have shown positive relationship with urbanization process.

Tertiary education shows varied results from income groups. Except for high income group, the diffusion of mobile cellular phone positively relates with tertiary education. However, in upper middle income group, none of the ICT indicators had significant relationships with tertiary education. At lower middle income group, fixed line internet shows negative relationship with tertiary education. This may resulted from the less penetration rate of fixed line internet, but more diffusion in mobile technology. This shows similar results in low income group as well. In low income group, fixed telephone subscription per 100 inhabitants had positive relations with tertiary education. This can be interpreted as increasing tertiary educational infrastructures, but still the logical gap between two is too wide.

\section{B. Validation of Grouped Analyses, Chow Test}

To test the hypothesis which analyses is conducted by group comparison of the results, dataset should be tested with its poolability. Thus, to strengthen the explanatory power of conducted panel analyses, this study conducts Chow test.

To conduct the Chow test, three groups are identified, which are high income (1), middle income (2), and low income (3). To test the poolability, upper and lower middle income group was combined into single middle income group. For each corresponding group, dummy variables were created from $\mathrm{d} 1$ to $\mathrm{d} 3$. By taking every dependent variable into regression, the Chow test results are depicted as following table.

\section{TABLE 9 Result FOR THE ChOW TEST}

\begin{tabular}{|l|l|}
\hline Economic Freedom (er) & All significant \\
Political Rights (pr) & fis100, fts100 significant \\
& fis100, fts100, pcmn \\
significant
\end{tabular}

As the result form the Chow test insists, tested poolability of this panel dataset is poolable. Therefore, conducting group analysis is acceptable with explanatory power based on grouped sample is acceptable for analyses objects. In addition, based on the result of the Chow test, following table is the result of group analysis, which group divided by income level of the countries.

Table 10 the Chow Test Result Table

\begin{tabular}{|c|c|c|c|c|c|}
\hline & Ef & pr & cl & urb & tedu \\
\hline fis100_1 & $\begin{array}{l}0.070 \\
(0.135)\end{array}$ & $\begin{array}{l}-0.362 \\
(0.595)\end{array}$ & $\begin{array}{l}-0.362 \\
(0.455)\end{array}$ & $\begin{array}{l}0.110 \\
(.251)\end{array}$ & $\begin{array}{l}-0.462 \\
(0.300)\end{array}$ \\
\hline fts100_1 & $\begin{array}{l}0.361 \\
(0.076)\end{array}$ & $\begin{array}{l}0.827 * \\
(0.362)\end{array}$ & $\begin{array}{l}\mathbf{0 . 8 0 0} \text { **** } \\
(0.277)\end{array}$ & $\begin{array}{l}0.376^{* * * *} \\
(.142)\end{array}$ & $\begin{array}{l}0.590 * * * * \\
(0.163)\end{array}$ \\
\hline pcmn_1 & $\begin{array}{l}- \\
\mathbf{0 . 1 6 8} * * * \\
(\mathbf{0 . 0 5 5})\end{array}$ & $\begin{array}{l}-0.101 \\
(0.238)\end{array}$ & $\begin{array}{l}-0.344 \\
(0.182)\end{array}$ & $\begin{array}{l}0.175 \\
(.103)\end{array}$ & $\begin{array}{l}0.011 \\
(0.138)\end{array}$ \\
\hline mcs100_1 & $\begin{array}{l}0.088 * * * \\
(0.028)\end{array}$ & $\begin{array}{l}0.012 \\
(0.112)\end{array}$ & $\begin{array}{l}0.146 \\
(0.085)\end{array}$ & $\begin{array}{l}0.101 \\
(0.052)\end{array}$ & $\begin{array}{l}0.284 * * * \\
(0.062)\end{array}$ \\
\hline
\end{tabular}




\begin{tabular}{|c|c|c|c|c|c|}
\hline fis100_2 & $\begin{array}{l}0.449 * * * \\
(0.055)\end{array}$ & $\begin{array}{l}-0.073 \\
(0.225)\end{array}$ & $\begin{array}{l}0.124 \\
(0.171)\end{array}$ & $\begin{array}{l}0.364 * * * \\
(0.103)\end{array}$ & $\begin{array}{l}0.366^{* * *} \\
(0.173)\end{array}$ \\
\hline fts100_2 & $\begin{array}{l}-0.022 \\
(0.034)\end{array}$ & $\begin{array}{l}1.118 * * * \\
(0.151)\end{array}$ & $\begin{array}{l}0.896 * * * \\
(0.116)\end{array}$ & $\begin{array}{l}0.231 * * * \\
(0.063)\end{array}$ & $\begin{array}{l}0.456 * * * \\
(0.104)\end{array}$ \\
\hline pcmn_2 & $\begin{array}{l}0.043 \\
(0.026)\end{array}$ & $\begin{array}{l}-0.244^{*} \\
(0.116)\end{array}$ & $\begin{array}{l}-0.266^{* *} * \\
(0.088)\end{array}$ & $\begin{array}{l}0.143 * * * \\
(0.023)\end{array}$ & $\begin{array}{l}-0.026 \\
(0.063)\end{array}$ \\
\hline mcs100_2 & $\begin{array}{l}0.045 * * * \\
(0.012)\end{array}$ & $\begin{array}{l}0.089 \\
(0.048)\end{array}$ & $\begin{array}{l}0.085 * * \\
(0.037)\end{array}$ & $\begin{array}{l}0.057 * * \\
(0.379)\end{array}$ & $\begin{array}{l}0.145^{* * * *} \\
(0.032)\end{array}$ \\
\hline fis100_3 & $\begin{array}{l}0.660 * * * \\
(0.205)\end{array}$ & $\begin{array}{l}2.151 * * * \\
(0.725)\end{array}$ & $\begin{array}{l}1.938 * * * \\
(0.553)\end{array}$ & $\begin{array}{l}0.348 \\
(0.379)\end{array}$ & $\begin{array}{l}-0.678 \\
(0.489)\end{array}$ \\
\hline fts100_3 & $\begin{array}{l}-0.199 * \\
(0.101)\end{array}$ & $\begin{array}{l}-0.135 \\
(0.394)\end{array}$ & $\begin{array}{l}-0.258 \\
(0.300)\end{array}$ & $\begin{array}{l}0.785 \text { *** } \\
(0.188)\end{array}$ & $\begin{array}{l}1.218 * * * \\
(0.230)\end{array}$ \\
\hline pcmn_3 & $\begin{array}{l}0.410^{*} \\
(0.078)\end{array}$ & $\begin{array}{l}0.354 \\
(0.316)\end{array}$ & $\begin{array}{l}0.363 \\
(0.241)\end{array}$ & $\begin{array}{l}0.475 * * * \\
(0.144)\end{array}$ & $\begin{array}{l}0.065 \\
(0.202)\end{array}$ \\
\hline mcs100_3 & $\begin{array}{l}-0.060 \\
(0.037) \\
\end{array}$ & $\begin{array}{l}-0.134 \\
(0.138)\end{array}$ & $\begin{array}{l}-0.081 \\
(0.105)\end{array}$ & $\begin{array}{l}0.0525 \\
(0.069)\end{array}$ & $\begin{array}{l}0.221 * * \\
(0.092)\end{array}$ \\
\hline d1 & $\begin{array}{l}62.647 \\
(3.901)\end{array}$ & $\begin{array}{l}60.360 \\
(16.826)\end{array}$ & $\begin{array}{l}76.814 \\
(12.849)\end{array}$ & $\begin{array}{l}28.503 \\
(7.225)\end{array}$ & $\begin{array}{l}3.764 \\
(10.823)\end{array}$ \\
\hline d2 & $\begin{array}{l}52.259 \\
(1.915) \\
\end{array}$ & $\begin{array}{l}52.147 \\
(8.757)\end{array}$ & $\begin{array}{l}58.765 \\
(6.687) \\
\end{array}$ & $\begin{array}{l}40.504 \\
(3.547) \\
\end{array}$ & $\begin{array}{l}17.603^{* * * *} \\
(4.448)\end{array}$ \\
\hline d3 & $\begin{array}{l}22.503 \\
(5.525)\end{array}$ & $\begin{array}{l}12.203 \\
(22.845)\end{array}$ & $\begin{array}{l}15.820 \\
(17.446)\end{array}$ & $\begin{array}{l}-2.379 \\
(10.231)\end{array}$ & $\begin{array}{l}2.130 \\
(14.791)\end{array}$ \\
\hline
\end{tabular}

Cells colored on yellow are the significant coefficients that are tested by the Chow test, and the numbers followed by independent variables are showing the income group. Economic Freedom Index was significant with every dependent variables with grouped analyses. Political Rights indicator were significant with two variables, which are fixed line internet subscription per 100 inhabitants, and fixed line telephone subscription per 100 inhabitants. Civil Liberty indicator was significant with three types of independent variables, which are fixed line internet subscription per 100 inhabitants, fixed line telephone subscription per 100 inhabitants, and percentage of population covered by mobile network. Urbanization indicator was only significant with fixed line internet subscription per 100 inhabitants, and lastly, tertiary education was significant with fixed line internet subscription per 100 inhabitants and fixed line telephone subscription per 100 inhabitants.

The results above by income group are followed. To start with, inside the high income group, following coefficients show extremely high significance $(\mathrm{p}<0.01)$. Firstly, percentage of population covered by mobile network is negatively correlated with economic freedom. Secondly, fixed line telephone subscription per 100 inhabitants is positively correlated with civil liberty. Third, tertiary education is also positively correlated with fixed line telephone subscription per 100 inhabitants. Lastly, along with economic freedom, mobile cellular phone subscription per 100 inhabitants show positive correlation with extremely high significance.

Secondly, middle income group shows 8 coefficients with extremely high significance. In relation with economic freedom, fixed line internet subscription per 100 inhabitants and mobile cellular phone subscription per 100 inhabitants have shown extremely high significance positively. With political rights, fixed line telephone subscription per 100 inhabitants shows extremely high significance positively with high coefficient as well (1.12). With civil liberty indicator, fixed telephone subscription shows positive correlation coefficient with extremely high significance. Urbanization is only recognized by fixed internet subscription per 100 inhabitants, and middle income group shows extremely high significance. Lastly, regarding tertiary education, among two significant variables, fixed line telephone subscription per 100 inhabitants shows positive correlation with dependent variable.

Lastly, the low income group shows only four extremely high significance from the result. Fixed line internet subscription is highly correlated with the economic freedom, political rights, and civil liberty with same (extremely high) significance. In addition, in tertiary education, fixed telephone subscription per 100 inhabitants is positively correlated with extremely high significance.

Comparison with pooled panel and grouped panel shows interesting differences as well. Firstly, in testing economic freedom with fixed line internet subscription, Firstly, with economic freedom indicator, the pooled panel results indicate that fixed line internet subscription per 100 inhabitants have shown positive relationship by reporting coefficient of 0.1432 at $1 \%$ statistical significance. However, in grouped analyses based on the result of the Chow test, insist that the fixed line internet subscription per 100 inhabitants are only significant at middle income group and low income group, with coefficient of 0.4499 and 0.6604 respectively at $1 \%$ statistical significant level. It is available to conclude that middle and low income group has higher correlation with the diffusion of Internet for improving economic freedom. In addition, when pooled panel reported the mobile subscription per 100 inhabitants marked coefficient of 0.012 with $1 \%$ statistical significance, high and middle income group have shown the aligned result by reporting 0.0889 and 0.0457 respectively at $1 \%$ statistical significance. However, the low income group reported insignificant level.

Secondly, political freedom in the pooled panel shows significant result only with fixed line telephone subscription per 100 inhabitants, with coefficient of -0.1864 at $1 \%$ statistical significance. In grouped analyses, high income group had marked coefficient of 0.8273 with comparatively low statistical significance level $(\mathrm{p}<0.05)$. The result by middle income group had shown significant result at coefficient of 1.1186 at $1 \%$ statistical significance. In low income group, fixed line Internet subscription per 100 inhabitants had marked coefficient of 2.151 at $1 \%$ statistical significance level.

At third, civil liberty at pooled panel shows result of negative relation with percentage of population covered by mobile network at coefficient of -0.0332 and positive relation with mobile cellular subscription per 100 inhabitants which marked coefficient of 0.0181 at $1 \%$ statistical significance. 
However, in grouped analyses, results indicate that civil liberty, in high income group, is highly correlated with fixed line telephone subscription per 100 inhabitants with coefficient of 0.8003 at $1 \%$ statistical significance level. In middle income group, in alignment with high income group, fixed line telephone subscription per 100 inhabitants reported coefficient of 0.8963 at $1 \%$ statistical significance. In low income group, fixed line internet subscription per 100 inhabitants had coefficient of 1.9380 at $1 \%$ statistical significance.

Contrasting result was reported with urbanization, between the pooled and grouped analyses. In pooled result, every dependent variables were reported to be significant at $1 \%$ statistical significance. However, in grouped data, only middle income group had shown significant result with fixed line internet subscription, which coefficient being 0.3649 at $1 \%$ statistical significance. At the same time, pooled result with fixed line internet per 100 inhabitants marked 0.0438 , which is far lower from the result of middle income group.

At last, pooled result of tertiary education shows three significant coefficients except percentage of population covered by mobile network. Fixed line internet subscription per 100 inhabitants marked 0.4298, fixed line telephone subscription per 100 inhabitants marked -0.2065 , and mobile cellular subscription per 100 inhabitants had marked 0.1047, all at the $1 \%$ statistical significance. In grouped result, by income level, the result were varied. In high income group, fixed line telephone subscription had significant coefficient of 0.5908 at $1 \%$ statistical significance. In middle income group, fixed line telephone subscription resulted in significant coefficient by 0.4567 at $1 \%$ statistical significance. Furthermore, the low income group also reported that fixed line telephone subscription at coefficient of 1.2182 with $1 \%$ statistical significance. In grouped analysis, three groups had shown the fixed line telephone subscription is the most significant to the tertiary education, and low income group marked the highest coefficient.

\section{CONCLUSION}

This study attempted to verify the relationship between the national level ICT diffusion with human progress indicators including political rights, civil liberty, economic freedom, urbanization, and tertiary education by cross-sectional timeseries analyses with 102 sample countries in division by income groups, from 2000 to 2011. To discover the given hypotheses, author conducted panel data analysis with comparison of fixed effect model and random effect model, with Hausman test in determination between those two. After, since the hypotheses aims to test the group effects, by conducting the Chow test, author tested whether the sample dataset is available to pool into groups, which were shown to have significant independent variables by each dependent variable and income level.
The research had tried to solve the given three problem statements, which are firstly, too much concentration on productivity analyses on studying the ICT diffusion, secondly, underlying limitations of Human Development Index of UNDP which contains the ICT diffusion at under level, and hard to detach the technology variable form composite index, and also the capability approach that overemphasizes the role of income in human development. Third was about with among limited references, the similar studies which conducted analyses between ICT diffusion and qualitative factors such as freedom, had limited sample countries with short time period that actually had difficulties on finding determinants for human progress and the impact from the technology diffusion.

In short, the conclusion of this study is that the ICT diffusion plays a role of determinant to human progress, which also means the $\mathrm{H} 1$ is approved. However, there prevails significant difference by group and also by technology. This study had set the remaining hypotheses into two categories, which are, firstly, the kind of technology, and secondly, by income level of the country. $H 2$ was, by different technological category inside the ICT, the potency of impact will be differed. Sub-hypotheses from $H 2$ is that, H2.1., Internet is the strongest determinant for driving human progress in measuring impact of human progress by ICT diffusion, and H2.2. Fixed line telephone is the weakest determinant in measuring impact of human progress by ICT diffusion. Based on the results, it is clear that different technologies affect dependent variables, which are human progress indicators, with different potency. In other words, H2. is passed. At the same time, fixed internet subscription per 100 inhabitants had the strongest explanatory power with dependent variables. Thus, the sub-hypothesis H2.1. is passed. However, H2.2. was rejected because the weakest determinant among ICT indicators was the mobile cellular phone subscription per 100 inhabitants considering its tested significance based on the Chow test.

\section{H3. The impacts on human progress by national level ICT} diffusion are differed by the income level of that country. was the third hypotheses to test. As mentioned just above, in order to analyze in groups, the study have conducted the Chow test to test the poolability of the panel. The results indicate that $H 3$. is passed. In our first analysis with Hausman tests, low income group had already shown insignificant coefficients. Also, based on the final result of the research, it is easily recognized that by income level, the difference in the size of impact is found. Furthermore, with sub hypotheses H3.1., it is also passed because the number of coefficients with the extremely high significance is concentrated in the middle income group. The results of the hypotheses tests are summarized in following table. Not only comparison between the income groups but also the comparison between the global-level analyses and grouped analyses were conducted. By comparing pooled results and grouped results, following conclusions can be made. Firstly, there is difference of technology which affects the human progress the most. For example, in case of 
urbanization, which had shown every independent variables with significant coefficients at $1 \%$ statistical significance, but in grouped analyses, only fixed internet subscription per 100 inhabitants of middle income group had significant coefficient, which is 0.3649 at $1 \%$ statistical significance. Therefore, by grouped analyses, the study have delivered stronger explanatory power than global-level analysis. At the same time, again the $\mathrm{H} 3$ was tested by this comparison.

However, H3.2. is difficult to be accepted by following reasons. Firstly, the number of significant coefficients in low income and high income marks the same at $1 \%$ statistical significance. Secondly, if we include the statistically significant level up to $5 \%$, low income group has more significant coefficients than high income group. Third, the coefficients of low income level that are statistically significant marked $0.6604,2.2151,1.9380$, and 1.2182 which all larger than the significant coefficients of the high income group, which are $-0.1683,0.0889,0.8003$, and 0.5908 . Therefore, the H3.2. is rejected. The Table 12 is the summary of results for hypotheses test for this study.

TABle 11 The Results of Hypotheses Tests

\begin{tabular}{|c|c|}
\hline Hypotheses & Result \\
\hline H1 & Passed \\
H2 & Passed \\
H2.1. & Passed \\
H2.2. & Rejected \\
H3 & Passed \\
H3.1. & Passed \\
H3.2. & Rejected \\
\hline
\end{tabular}

This research was motivated from following motivations. The first motivation was to broaden the research area of ICT diffusion and its impact from economic improvement to human progress. Secondly, the underlying indicators that are measuring human progress, such as Human Development Index by UNDP, is comprehensive but the composition is widely criticized. Third, even though there were small number of similar researches, similar approaches such as BaliamouneLutz [30], prevailing studies had limited sample size with shorter period of empirical analysis, which is difficult to catch the effects ICT diffusion dynamics of $21^{\text {st }}$ century. Therefore the study was conducted with considering dependent variables for human factors, with longer time period and larger sample to determine the effects of ICT diffusion.

Based on the results, this research was available to give further steps on provision of solution to the problem statement. By adopting qualitative data reported from number of institutions, this research had expanded the study of ICT diffusion from productivity analysis. Not only expansion but also it had empirically proven that the ICT diffusion affects human progress at macro level. Secondly, by excluding the income factor in dependent variables, and including the economic freedom, this research can tell the better representation of human progress than prevailing studies. Furthermore, not only single source or single index, but comprising number of indices and datasets from varied sources under critical examination through literatures enhances the reliability of this study.

Contributions of this research are summarized as follows. Firstly, since the most potent technology and weakest technology among ICT is verified, it can provide the direction of national and international level ICT development master plan which goal is to make a country where the human being can actually bring human progress Not only at the point of technological target, but also since the analyses were conducted by income groups, it helps policymakers in different income groups to gain policy implications. For example, because the internet was the strongest determinant for human progress positively at the low income group, it provides targeted policy implications to lower income group who has high demand in making human progress domestically. Second, to the academia, because this is one of the research that have attempted to bridge between the human factor by diffusion of technology at cross-country level, this research can inspire other scholars to conduct similar researches with different countries, different indicators, especially different technological factors that makes human progress.

However, there also prevails limitations in this study. Since regression analysis does not implies causality relationship, it is difficult to determine whether the ICT diffusion is the cause of human progress, vice versa. Secondly, selected variables for both human factors and ICT diffusion was limited because of data availability. By supplementing reliable data with larger datasets, more accurate empirical analysis is available in the future. In addition, considering the time lags within this research will strengthen the explanatory power for this topic.

Again, based on this research, nonetheless it is emphasized that the importance of ICT diffusion in human progress. Selected dependent variables not only implies the value of ICT diffusion, or wider, technology diffusion, but also the considerations of human factor in compositely is also another point of emphasis that author like to provide. Issues of human progress should not be considered as an event, but also should be continued with high interest in relation with technical changes. This research only provided one aspect of technology, which is information and communication technology, with limited human progress variables. Further examination with effort and dedication in this issue will contribute the world as a whole.

\section{VI.REFERENCES}

[1] ITU, The World in 2013: ICT Facts and Figures: International Telecommunications Union, 2013

[2] J. Mariscal, "Digital divide in a developing country," Telecommunications Policy, vol. 29, pp. 409-428, 2005

[3] UNDP, "Human Development Report 2013 - The Rise of the South: Human Progress in a Diverse World," 2013. 
H. Packard, "Global Citizenship Report," Retrieved November, vol. 3, p. 2006, 2006.

[5] UNCTAD, E-Commerce and Development Report 2002 vol. 2 United Nations Publications, 2002.

[6] E. Helpman, General purpose technologies and economic growth: The MIT press, 1998.

[7] S. Basu and J. Fernald, "Information and Communications Technology as a General-Purpose Technology: Evidence from US Industry Data," German Economic Review, vol. 8, pp. 146-173, 2007.

[8] D. Virchow and J. von Braun, "Okinawa Charter on Global Information Society," in Villages in the Future, ed: Springer, 2001, pp. 251-253.

[9] L. Soeftestad and M. Sein, "ICT and development: east is east and west is west and never the twain shall meet."

[10] D. Quah, "The weightless economy in economic development," 1999.

[11] D. Quah, "ICT clusters in development: Theory and evidence," EIB papers, vol. 6, pp. 85-100, 2001.

[12] R. M. Solow, "A contribution to the theory of economic growth," The quarterly journal of economics, vol. 70, pp. 65-94, 1956.

[13] B. Wellenius, "Telecommunications in developing countries," Telecommunications Policy, vol. 1, pp. 289-297, 1977.

[14] A. P. Hardy, "The role of the telephone in economic development," Telecommunications policy, vol. 4, pp. 278-286, 1980

[15] F. J. Cronin, E. B. Parker, E. K. Colleran, and M. A. Gold "Telecommunications infrastructure and economic growth: An analysis of causality," Telecommunications Policy, vol. 15, pp. 529-535, 1991.

[16] A. Colecchia and P. Schreyer, "ICT investment and economic growth in the 1990s: is the United States a unique case?: comparative study of nine OECD countries," Review of Economic Dynamics, vol. 5, pp. 408-442, 2002.

[17] E. H.-h. Wang, "ICT and economic development in Taiwan analysis of the evidence," Telecommunications Policy, vol. 23, pp. 235-243, 1999.

[18] R. Heeks, "ICT4D 2.0: The next phase of applying ICT for international development," Computer, vol. 41, pp. 26-33, 2008.

[19] H.-J. Jung, K.-Y. Na, and C.-H. Yoon, "The role of ICT in Korea's economic growth: Productivity changes across industries since the 1990s," Telecommunications Policy, vol. 37, pp. 292-310, 2013.

[20] G. Cette, J. Mairesse, and Y. Kocoglu, "ICT diffusion and potential output growth," Economics Letters, vol. 87, pp. 231-234, 2005.

[21] S.-Y. T. Lee, R. Gholami, and T. Y. Tong, "Time series analysis in the assessment of ICT impact at the aggregate level-lessons an implications for the new economy," Information \& Management, vol. 42, pp. 1009-1022, 2005

[22] C. Avgerou, "How can IT enable economic growth in developing countries?," Information Technology for Development, vol. 8, pp. $15-28,1998$.

[23] A. K. Sen, "Development as Capability Expansion"," ed, 1990.

[24] M. Hopkins, "Human development revisited: A new UNDP report," World Development, vol. 19, pp. 1469-1473, 1991.

[25] A. D. Sagar and A. Najam, "The human development index: a critical review," Ecological economics, vol. 25, pp. 249-264, 1998. M. McGillivray, "The Human Development Index: yet another redundant composite development indicator?," World Development, vol. 19, pp. 1461-1468, 1991.

[27] M. N. Baliamoune, "On the measurement of human well-being: fuzzy set theory and Sen's capability approach," World Institute for Development Economic Research (UNU-WIDER)2004.

[28] F. Caselli and W. J. I. Coleman, "Cross-country technology diffusion: The case of computers," National Bureau of Economic Research2001.

[29] A. Al-mutawkkil, A. Heshmati, and J. Hwang, "Development of telecommunication and broadcasting infrastructure indices at the global level," Telecommunications Policy, vol. 33, pp. 176-199, 2009.

$$
\text { M. Baliamoune-Lutz, "An analysis of the determinants and effects }
$$
of ICT diffusion in developing countries," Information Technology for development, vol. 10, pp. 151-169, 2003.

M. Porter, J. Sachs, P. Cornelius, J. McArthur, and K. Schwab, "World Competitiveness Report 2001-2002," ed: New York: Oxford University Press, 2002.

A. G. Flor, "ICT and poverty: The indisputable link," in SEARCA, paper for the Third Asian Development Forum on "Regional Economic Cooperation in Asia and the Pacific", Asian Development Bank, 2001, pp. 11-14.

P. N. Howard and N. Mazaheri, "Telecommunications reform, Internet use and mobile phone adoption in the developing world," World Development, vol. 37, pp. 1159-1169, 2009.

UN, "Universal Declaration of Human Rights," Resolution adopted by the General Assembly, vol. 10, 1948.

F. Shirazi, R. Gholami, and D. Añón Higón, "The impact of information and communication technology (ICT), education and regulation on economic freedom in Islamic Middle Eastern countries," Information \& Management, vol. 46, pp. 426-433, 2009.

F. Shirazi, O. Ngwenyama, and O. Morawczynski, "ICT expansion and the digital divide in democratic freedoms: An analysis of the impact of ICT expansion, education and ICT filtering on democracy," Telematics and Informatics, vol. 27, pp. 21-31, 2010. L. Bertinelli and D. Black, "Urbanization and growth," Journal of Urban Economics, vol. 56, pp. 80-96, 2004.

G. Harter, J. Sinha, A. Sharma, and S. Dave, "Sustainable urbanization: the role of ICT in city development," Booz \& Company Inc., available at http://www.booz.com/media/uploads/Sustainable_Urbanization.pd $f, 2010$.

[39] A. J. Njoh, "Urbanization and development in sub-Saharan Africa," Cities, vol. 20, pp. 167-174, 2003.

[40] J.-W. Lee, "Education for technology readiness: prospects for developing countries," Journal of Human Development, vol. 2, pp. 115-151, 2001.

[41] S. F. Buchele, "Using OLPC laptop technology as a computer science case study teaching tool," Journal of Computing Sciences in Colleges, vol. 24, pp. 130-136, 2009.

[42] R. Fonseca and J. Pal, "Computing Devices for All: Creating and selling the low-cost computer," pp. 11-20.

[43] K. Downing, "Information technology, education and health care Constructivism in the 21st century," Educational Studies, vol. 27, pp. 229-235, 2001.

[44] K. C. Green and S. W. Gilbert, "Great expectations: Content, communications, productivity, and the role of information technology in higher education," Change: The magazine of higher learning, vol. 27, pp. 8-18, 1995.

[45] B. Baltagi, Econometric analysis of panel data: Wiley. com, 2008.

[46] W. Bank, Global Economic Prospects, Volume 7, June 2013 vol. 7 : World Bank Publications, 2013.

[47] J. M. Wooldridge, Econometric analysis of cross section and panel data: The MIT press, 2002.

[48] U. Kohler and F. Kreuter, Data analysis using Stata: Stata Press, 2005.

[49] W. H. Greene, Econometric Analysis, 6/e: Pearson Education India, 2008.

[50] J. H. Stock and M. W. Watson, Introduction to Econometrics: Global Edition: Pearson Education, 2012.

[51] J. Dinardo, J. Johnston, and J. Johnston, "Econometric methods," Forth Edition) McGraw-Hill Companies, Inc, pp. 204-326, 1997.

[52] G. C. Chow, "Tests of equality between sets of coefficients in two linear regressions," Econometrica: Journal of the Econometric Society, pp. 591-605, 1960.

[53] F. M. Fisher, "Tests of equality between sets of coefficients in two linear regressions: an expository note," Econometrica: Journal of the Econometric Society, pp. 361-366, 1970.

[54] D. N. Gujarat1, "Basic econometrics," ed: McGraw-Hill New York, 2004. 
Sang-Oun LEE is a Masters Candidate of Technology Management, Economics and Policy Program at Seoul National University. He was born in Seoul in 1988. In 2007, he graduated Daeduk High School, and owns Bachelor's Degree in International Liberal Studies, in concentration of Economics and Political Philosophy, at Waseda University, Tokyo, Japan, from 2012. He now serves as a researcher at Smart-Media Convergence Policy Research Center at Seoul National University, Seoul, Korea, and his main research focus is policy for promoting development via ICT.

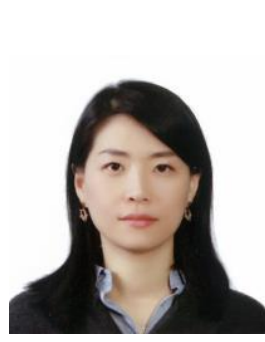

Ahreum Hong is Ph.D in Economics and Research Professor at Smart Media Policy Research Center at Technology Management, Economics and Policy Program (http://temep.snu.ac.kr) in Seoul National University and also a lecturer in economics at Nam Seoul University. For six years, she also has worked as a researcher of CPRC (Communications Policy Research Center) program that is managed by the KCC (Korea Communications Commission), South Korea. This work is about the regulation and policy research of Korea ICT.

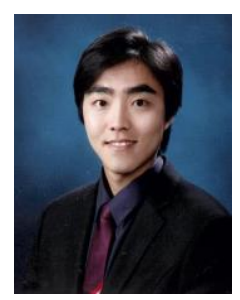

Changjun. LEE is a Ph.D student at Technology Management, Economics, and Policy Program in Seoul national university. He was born at Busan in 1983. In 2002, he graduated Geochang High School and graduated Yonsei University majoring Biology and Chemistry in 2010. He is now at Seoul national university working in Smart Media Policy Research Center and his research area is policy for promoting the contents and smart-media industry.

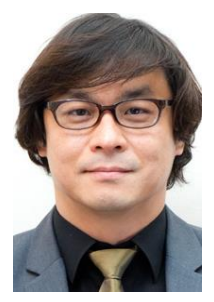

Junseok Hwang is a professor at Technology Management, Economics, and Policy Program (http://temep.snu.ac.kr) in Seoul National University. $\mathrm{He}$ is also a chief of at Smart Media Policy Research Center in Seoul National University. For last 10 years, he had served for the director of Communications Policy Research Center and principal professor of International IT Policy Program at Seoul National University.

He obtained B.S. in Mathematics at Yonsei University, Master's Degree in Telecommunications at University of Colorado and his Ph.D in Information Science and Telecommunications at University of Pittsburgh. He had taught at Syracuse University as an assistant professor for three years before taking current position at Seoul National University. His main research field consists Network Economics, Technological Innovation in ICT, Convergence Policy, and so forth. 